\title{
Membangun Motivasi Kerja Guru Dalam Menyiapkan Sumber Daya Manusia Indonesia Yang Berkualitas \\ (Analisis Teori Motivasi Abraham Maslow Di SMK Negeri 57 Jakarta)
}

\author{
Sudiarto \\ Dosen Fakultas Ekonomi Universitas Pamulang \\ Email : sudiarto132239@gmail.com
}

\begin{abstract}
ABSTRAK
Penelitian ini bertujuan untuk menganalisis tentang implikasi teori Hierarki kebutuhan Abraham Maslow berdasarkan fenomena yang terjadi di Lingkungan SMK Negeri 57 Jakarta, dan memperoleh bukti empirik serta kesimpulan tentang Analisis Teori Motivasi Abraham Maslow dikaitkan dengan Membangun Motivasi Kerja Guru Dalam Menyiapkan Sumber Daya Manusia Indonesia Yang Berkualitas Di SMK Negeri 57 Jakarta.

Penelitian ini menggunakan pendekatan kualitatif. Alasan utama menggunakan metode kualitatif adalah sesuai dengan tujuan penelitian, yaitu ; melakukan kajian terhadap keadaan saat ini yang terjadi di lokus penelitian, yang memperlihatkan gejala atau fenomena menuju ke arah munculnya suatu permasalahan. Akan tetapi permasalahan yang ada masih belum jelas, kompleks, dinamis, menyeluruh serta penuh makna. Permasalahan yang berhubungan dengan Pengelolaan Sumber Daya Manusia, sebagai faktor kunci dalam keberhasilan pelaksanaan proses belajar mengajar yang hasil akhirnya berkaitan dengan kualitas sumber daya manusia Indonesia. Informan terdiri dari para wakil kepala sekolah, dan guru. Pengumpulan data dilakukan dengan cara observasi, wawancara mendalam serta percakapan percakapan informal.

Hasil penelitian ini menunjukkan bahwa terdapat aspek-aspek Motif, Menyenangi pekerjaan, Prestasi dan Kepuasan kerja serta komunikasi yang merupakan hal yang paling dominan dalam motivasi kerja guru di SMK Negeri 57 Jakarta. Kesimpulan penelitian ini adalah Manajemen SMK Negeri 57 Jakarta, tidak konsisten dalam menerapkan kebijakan membangun motivasi kerja guru, karena tidak pernah disusun suatu perencanaan tentang pelatihan untuk membangun motivasi kerja guru yang tertuang di dalam program kerja kepala sekolah dan wakil kepala sekolah, tidak memiliki sistem reward dan funishment untuk para guru, tidak memberikan kenyamanan dan keamanan dalam melaksanakan tugas.
\end{abstract}

Kata kunci: Motivasi kerja, Guru, Manajemen SMK Negeri 57 Jakarta. 


\section{PENDAHULUAN}

\section{Latar Belakang Masalah}

Peningkatan

kualitas

pendidikan perlu dilakukan secara sinergis pada setiap jenjang/tingkat pendidikan di Indonesia. Pelaksanaan pendidikan di Indonesia mengacu kepada tujuan pendidikan nasional sebagaimana yang tertera dalam Undang-Undang Nomor 20 Tahun 2003 tentang Sistem Pendidikan Nasional yang menyebutkan bahwa pendidikan nasional bertujuan untuk mengembangkan kemampuan dan membentuk watak serta peradapan bangsa, yang bermartabat dalam rangka mencerdaskan kehidupan bangsa, bertujuan untuk berkembangnya potensi peserta didik agar menjadi manusia yang beriman dan bertaqwa kepada Tuhan Yang Maha Esa, berakhlak mulia, sehat, berilmu, cakap, kreatif, mandiri dan menjadi warga Negara yang demokratis serta bertanggung jawab.Tujuan pendidikan nasional dapat diwujudkan dengan pelaksanaan pembelajaran pada institusi pendidikan atau sekolah. Karena sekolah merupakan salah satu sarana untuk belajar. Hakikat belajar adalah adanya perubahan tingkah laku, Hamzah B.Uno (2012) dalam Nurfuadi (2012:22) menjelaskan; belajar dapat diartikan sebagai suatu proses perubahan tingkah laku sebagai hasil dari latihan pengalaman individu akibat interaksi dengan lingkungannya. Perubahanperubahan yang terjadi sebagai akibat dari hasil perbuatan belajar seseorang dapat berupa kebiasaankebiasaan, kecakapan atau dalam bentuk pengetahuan, sikap dan keterampilan.
Karena tujuan pembelajaran merupakan turunan dari tujuan Pendidikan Nasional. Pencapaian tujuan pendidikan nasional sebagaimana yang tertera dalam Undang-Undang Sistem Pendidikan Nasional tersebut dapat dilakukan dengan memberdayakan tenaga pendidik atau guru yang bertugas di setiap tingkat satuan pendidikan di Indonesia. Karena pada dasarnya pendidikan yang diselenggarakan berdasarkan amanat Undang-Undang Sistem Pendidikan Nasional yaitu dalam rangka menyiapkan sumberdaya manusia yang berkualitas. Oleh sebab itu perlu didukung dengan penyediaan pendidikan yang berkualitas. Peningkatan kualitas pendidikan juga harus didukung dengan peningkatan kualitas tenaga pendidik. Karena tenaga pendidik merupakan komponen penting dalam rangka penyiapan sumber daya manusia. Oleh karena kedudukan guru yang sangat penting dalam proses pembelajaran di sekolah, maka perlu dilakukan suatu langkah pemberdayaan guru untuk meningkatkan kualitas pendidikan di Indonesia.

Pemberdayaan tenaga pendidik dalam rangka peningkatan kualitas pendidikan di Indonesia perlu dilaksanakan dengan cara membangun motivasi kerja baik dari dalam maupun dari luar diri individu guru yang bersangkutan. Motivasi sebagaimana yang dikemukakan oleh Malayu S.P. Hasibuan dalam Danang Sunyoto (2013:191); Motivasi mempersoalkan bagaimana cara mendorong gairah kerja bawahan, agar mereka mau bekerja keras dengan memberikan semua 
kemampuan dan keterampilannya untuk mewujudkan tujuan perusahaan ini penting karena dengan motivasi diharapkan setiap individu karyawan mau bekerja keras dan antusias untuk mencapai produktivitas kerja yang tinggi. Selanjutnya Malayu S.P. Hasibuan menyebutkan pengertian motivasi adalah suatu perangsang keinginan (want) daya penggerak kemauan bekerja seseorang; setiap motif mempunyai tujuan tertentu yang ingin dicapai. Untuk membangkitkan dorongan atau kekuatan yang muncul dari dalam diri individu pada suatu organisasi dalam rangka melaksanakan tugas dan tanggung jawab yang dilimpahkan, maka perlu dilakukan suatu upaya untuk membangun motivasi dalam setiap diri individu. Sehubungan dengan penulisan usulan penelitian ini, individu yang dimaksud adalah guru yang diberi tanggung jawab untuk melaksanakan proses belajar mengajar di sekolah yang bertujuan untuk menyiapkan sumber daya manusia yang berkualitas.

Sumber daya manusia yang berkualitas seperti yang dikemukakan oleh Sedarmayanti (2009:1-2); Pada masa pemerintahan Orde Baru kebijakan arah dan tujuan pembangunan tertuang dalam Rencana Pembangunan Lima Tahun (PELITA) yang tercantum dalam setiap Garis-Garis Besar Haluan Negara (GBHN) dimana didalamnya terdapat tujuan pembangunan nasional dan tercantum kriteria manusia yang berkualitas.

Sehubungan

dengan

penyelenggaraan pendidikan menengah kejuruan, di DKI Jakarta saat ini terdapat 63 SMK dengan berbagai Program keahlian, dan SMK Negeri 57 adalah salah satu dari 63 SMK di DKI Jakarta. Sebagai salah institusi penyelenggara pendidikan. Sekolah Menengah Kejuruan (SMK) Negeri 57 Jakarta dengan program keahlian pariwisata, berupaya menyiapkan tenaga kerja pada tingkat pelaksana di bidang pariwisata. Pada hakikatnya penyelenggaraan pendidikan di SMK dengan memberikan bekal pengetahuan dan keterampilan bagi peserta didiknya.

Dengan tujuan memenuhi tuntutan dunia industri sebagai pengguna tamatan SMK. Mengingat pentingya peranan guru dalam rangka mempersiapkan sumber daya manusia Indonesia yang berkualitas melalui pendidikan, maka guru perlu dibangun motivasinya dalam rangka menyiapkan sumber daya manusia Indonesia yang berkualitas. Mengacu kepada kenyataan yang terjadi di lapangan sebagaimana yang dikemukakan pada latar belakang di atas. Penulis melakukan suatu penelitian yang berjudul "Membangun Motivasi Kerja Guru Dalam Menyiapkan Sumber Daya Manusia Yang Berkualitas"

\section{Fokus Masalah}

Setelah melakukan pengamatan selama penetapan program wajib belajar 12 tahun di SMK Negeri 57 Jakarta, maka ditetapkan SMK Negeri 57 sebagai tempat penelitian sekaligus sebagai situasi sosial (place), dan guru-guru adalah orangorang (actor), yang terlibat dalam proses belajar mengajar (activity). Fokus permasalahan penelitian ini diarahkan kepada: 
1. Aktivitas-aktivitas guru dalam melaksanakan tugas dan tanggung jawab yang dibebankan oleh Manajemen SMK Negeri 57 Jakarta.

2. Pemberian penghargaan atau imbalan yang dilakukan oleh manajemen sekolah atas kegiatan yang dilakukan oleh para guru.

3. Aktivitas-aktivitas yang dilakukan oleh SMK Negeri 57 Jakarta dalam membangun motivasi kerja guru.

\section{Rumusan Masalah}

Mengacu kepada latar belakang permasalahan yang sudah dikemukakan pada bagian terdahulu dalam tulisan ini. Pada kesempatan ini fokus masalah yang dikemukakan dalam penelitian ini adalah motivasi kerja guru, maka rumusan masalah yang diajukan dalam penelitian ini sebagai berikut:

"Bagaimanakah Langkah-langkah Strategis Yang Dilaksanakan Oleh Manajemen SMK Negeri 57 Jakarta Dalam Membangun Motivasi Kerja Guru?"

\section{Tujuan Penelitian}

Tujuan dalam penelitian ini untuk mengetahui dan menemukan jawaban atas rumusan masalah di atas, sebagaimana yang tertulis dalam fokus masalah yaitu:

1. Aktivitas-aktivitas guru dalam melaksanakan tugas dan tanggung jawab yang dibebankan oleh Manajemen SMk Negeri 57 Jakarta.

2. Pemberian penghargaan atau imbalan yang dilakukan oleh manajemen sekolah atas kegiatan yang dilakukan oleh para guru.
3. Aktivitas-aktivitas yang dilakukan oleh SMK Negeri 57 Jakarta dalam membangun motivasi kerja guru.

\section{Manfaat Penelitian}

1. Manfaat Keilmuan

Terhadap khasanah keilmuan, dapat berguna bagi kemajuan ilmu pengetahuan Manajemen Sumber Daya Manusia dan memberikan masukan kepada penentu kebijakan di SMK Negeri 57 Jakarta yang berkenaan dengan membangun motivasi kerja guru dalam mempersiapkan sumber daya manusia yang berkualitas.

\section{Manfaat Praktis}

1. Dengan diketahuinya aktivitasaktivtas yang dilakukan oleh guruguru di SMK Negeri 57 Jakarta dalam melaksanakan tugas dan tanggung jawab yang dibebankan oleh Manajemen SMK Negeri 57 Jakarta, maka akan bermanfaat untuk merencanakan program atau kegiatan yang merata atau proporsional dan profesional.

2. Dengan diketahuinya pemberian penghargaan atau imbalan yang dilakukan oleh manajemen sekolah atas kegiatan yang dilakukan oleh para guru, maka akan bermanfaat untuk membuat suatu standar pemberian penghargaan atau imbalan sesuai dengan peraturan yang berlaku.

3. Dengan diketahuinya aktivitasaktivitas yang dilakukan oleh SMK Negeri 57 Jakarta dalam membangun motivasi kerja guru, maka akan bermanfaat untuk merancang suatu program atau kegiatan yang membangun motivasi kerja guru SMK Negeri 57 Jakarta. 


\section{KERANGKA PEMIKIRAN}

\begin{tabular}{|c|c|c|}
\hline $\begin{array}{l}\quad \text { KONDISI } \\
\quad \text { NYATA: } \\
\text { Kelambatan } \\
\text { Turunnya Dana } \\
\text { (TKD) Dari } \\
\text { Pemprov DKI } \\
\text { Jakarta } \\
\text { Guru Dituntut } \\
\text { Memenuhi Jam } \\
\text { Mengajar 24 } \\
\text { Jam Dalam } 1 \\
\text { Minggu } \\
\text { Guru Tidak } \\
\text { Memperoleh } \\
\text { Hasil Atau } \\
\text { Imbalan Atas } \\
\text { Kegiatan } \\
\text { (Kompensasi) } \\
\text { Azas Keadilan } \\
\text { Dalam } \\
\text { Mencantumkan } \\
\text { Nama Guru } \\
\text { Dalam Kegiatan }\end{array}$ & $\begin{array}{l}\text { HASIL ANALISIS } \\
\text { Proposisi 1; Proses manajemen } \\
\text { secara umum, dalam hal } \\
\text { pengelolaan program kegiatan, } \\
\text { pendelegasian tugas dan } \\
\text { wewenang sehubungan dengan } \\
\text { pelaksanaan tugas dan tanggung } \\
\text { jawab sebagai guru. } \\
\text { Proposisi 2: Pengelolaan } \\
\text { Sumber daya manusia, } \\
\text { berkaitan dengan pemerataan } \\
\text { keikutsertaan dalam kegiatan, } \\
\text { penghargaan atas pencapaian } \\
\text { prestasi yang dicapai oleh para } \\
\text { guru. } \\
\text { Proposisi 3: Pemberian motivasi } \\
\text { dalam bentuk tindakan memotivasi } \\
\text { sehingga guru mau mengerahkan } \\
\text { segenap kemampuan yang } \\
\text { dimilikinya dalam melaksanakan } \\
\text { tugas dan menghasilkan tamatan } \\
\text { yang sesuai dengan tujuan } \\
\text { pendidikan nasional. }\end{array}$ & $\begin{array}{l}\text { Proposisi 1; Proses } \\
\text { manajemen secara } \\
\text { umum, dalam hal } \\
\text { pengelolaan program } \\
\text { kegiatan, pendelegasian } \\
\text { tugas dan wewenang } \\
\text { sehubungan dengan } \\
\text { pelaksanaan tugas dan } \\
\text { tanggung jawab } \\
\text { sebagai guru. } \\
\text { Proposisi 2: Penge- } \\
\text { lolaan Sumber daya } \\
\text { manusia, berkaitan } \\
\text { dengan pemerataan } \\
\text { keikutsertaan dalam } \\
\text { kegiatan, penghargaan } \\
\text { atas pencapaian } \\
\text { prestasi yang dicapai } \\
\text { oleh para guru. } \\
\text { Proposisi 3: Pemberian } \\
\text { motivasi dalam ben- } \\
\text { tuk tindakan memo- } \\
\text { tivasi sehingga guru } \\
\text { mau mengerahkan } \\
\text { segenap kemampuan } \\
\text { yang dimilikinya dalam } \\
\text { melaksanakan tugas } \\
\text { dan menghasilkan } \\
\text { tamatan yang sesuai } \\
\text { dengan tujuan } \\
\text { nendidikan nasional. }\end{array}$ \\
\hline
\end{tabular}

\section{Gambar 1.1. Kerangka Pemikiran}

\section{TINJAUAN PUSTAKA}

Setiap aktivitas atau kegiatan yang dilaksanaka pada suatu organisasi, pasti ada tujuan tujuan yang hendak dicapai, demikian juga halnya dengan pemberian motivasi kepada pegawai atau idnividu. Sehubungan dengan pemberian 
motivasi yang dibangun di dalam diri guru Sekolah menengah Kejuruan (SMK) tidak terlepas dari tujuan yang hendak dicapai, yaitu terciptanya semangat kerja dan rasa tanggung jawab atas pelaksanaan pekerjaan yang dibebankan kepada guru yang bersangkutan. Sehubungan dengan tujuan pemberian motivasi ini Danang Sunyoto (2013:198) menyebutkan:

"Tujuan pemberian motivasi antara lain mendorong gairah dan semangat kerja karyawan, meningkatkan moral dan kepuasan kerja karyawan, meningkatkan produktivitas kerja karyawan, memertahankan loyalitas dan kestabilan karyawan perusahaan, meningkatkan kedisiplinan dan menurunkan tingkat absensi karyawan, menciptakan suasana dan hubungan kerja yang baik, meningkatkan kreativitas dan partisipasi karyawan, meningkatkan kesejahteraan karyawan, mempertinggi rasa tanggung jawab karyawan terhadap tugas-tugasnya".

Dalam pelaksanaan prsoes belajar mengajar di sekolah, guru merupakan faktor kunci atas keberhasilan pelaksanaan proses belajar mengajar tersebut. Di pundak para gurulah terdapat tugas dan tanggung jawab dalam rangka mempersiapkan sumber daya manusia yang berkualitas. Keberhasilan seorang guru manakala ia mampu menghantarkan para siswanya menyerap ilmu pengetahuan yang diberikan dan menerapkannya dalam kehidupan di masyarakat. Nurfuadi (2012:51) menyatakan; Guru sebagai tenaga pendidik yang tugas utamanya mengajar, memiliki karaktersitik dan kepribadian yang sangat berpengaruh terhadap keberhasilan pengembangan sumber daya manusia". Sosok guru adalah individu yang selalu menjadi panutan dan menginspirasi para siswanya, kiranya keberadan guru perlu diakui dan diberikan penghargaan atas pengabdian yang diberikan. Undang-Undang Republik Indonesia Nomor 14 Tahun 2005, pasal 1 ayat 2 menyebutkan definisi guru sebagai berikut;"Guru adalah pendidik profesional dengan tugas utama mendidik, mengajar, membimbing, mengarahkan, melatih, menilai, dan mengevaluasi peserta didik pada pendidikan anak usia dini jalur pendidikan formal, pendidikan dasar, dan pendidikan menengah". Berdasarkan penyataan ini guru sebagai suatu profesi tidak dilihat dari status kepegawaiannya di dalam satu sekolah.

Pada kenyataannya guru yang bertugas di suatu sekolah memiliki status yang bermacam-macam, penjelasan tentang status guru ini sebagaimana yang tertera di dalam http://www.scribd.com/doc/1466591 42/Pengertian-Status-KepegawaianPNS yang diposkan oleh Candra Wiranata; Pengertian Status Kepegawaian PNS, PNS Diperbantukan, PNS Depag, GTY/PTY, GTT/PTT Provinsi, GTT/PTT Kab/Kota, Guru Bantu Pusat, Guru Bantu Sekolah sebagai berikut :

a) PNS adalah pegawai negeri atau aparatur negara yang bukan militer

b) PNS Diperbantukan adalah PNS yang mendapat tugas mengajar di Sekolah bukan milik pemerintah (Swasta) 
c) PNS Depag adalah pegawai negeri yang diangkat oleh Departemen Agama

d) GTY/PTY adalah adalah guru tetap yayasan dan pegawai tetap yayasan yang diangkat dan mendapat gaji dari Yayasan

e) GTT/PTT Provinsi adalah guru tidak tetap dan pegawai tidak tetap yang diangkat oleh Provinsi

f) GTT/PTT Kab/Kota adalah guru tidak tetap dan pegawai tidak tetap yang diangkat oleh Kab/Kota

g) Guru Bantu Pusat adalah guru non PNS yang diangkat dan di gaji olehpemerintah pusat

h) Guru Bantu Sekolah adalah guru yang diangkat oleh kepala sekolah dan di gaji dengan dana BOS atau dana yang bersumber dari sekolah

i) Tenaga honor adalah tenaga pendidik selain guru yang kerja di lingkungan pendidikan.

http://www.scribd.com/doc/1466591 42/Pengertian-Status-KepegawaianPNS diakses tanggal 16 April 2013

\section{a. Penghargaan Terhadap Guru}

Status kepegawain guru di suatu sekolah akan menentukan tingkat penghargaan yang akan diberikan oleh manajemen sekolah yang bersangkutan. Berkaitan pemberian penghargaan dan pengakuan atas profesi guru ini pemerintah telah memberikan Tunjangan Profesi guru, seperti yang tercantum di dalam Undang-undang Republik Indonesia Nomor 14 Tahun 2005 tentang Guru dan Dosen. Pemberian Tunjangan profesi guru ini didasarkan atas sertifikasi yang dilakukan oleh Kementrian pendidikan dan Kebudayaan Republik Indonesia, dengan menunjuk perguruan Tinggi sebagi penyelenggara Sertifikasi guru.

Undang-undang Republik Indonesia Nomor 14 Tahun 2005 Pasal 8 menyebutkan: "Guru wajib memiliki kualifikasi akademik, kompetensi, sertifikat pendidik, sehat jasmani dan rohani, serta memiliki kemampuan untuk mewujudkan tujuan pendidikan nasional". Selanjutnya tentang sertifikasi Undang-undang Republik Indonesia Nomor 14 Tahun 2005 Pasal 11 menyebutkan:

1) Sertifikat pendidik sebagaimana dimaksud dalam Pasal 8 diberikan kepada guru yang telah memenuhi persyaratan.

2) Sertifikasi pendidik diselenggarakan oleh perguruan tinggi yang memiliki program pengadaan tenaga kependidikan yang terakreditasi dan ditetapkan oleh Pemerintah.

3) Sertifikasi pendidik dilaksanakan secara objektif, transparan, dan akuntabel.

4) Ketentuan lebih lanjut mengenai sertifikasi pendidik sebagaimana dimaksud pada ayat (2) dan ayat (3) diatur dengan Peraturan Pemerintah.

Berkaitan dengan pemberian penghargaan terhadap profesi guru, Undang-undang Republik Indonesia Nomor 14 Tahun 2005 Pasal 15 ayat (1):

" Penghasilan di atas kebutuhan hidup minimum sebagaimana dimaksud dalam Pasal 14 ayat (1) huruf a meliputi gaji pokok, tunjangan yang melekat pada gaji, serta penghasilan lain berupa tunjangan profesi, tunjangan fungsional, tunjangan khusus, dan maslahat tambahan yang terkait 
dengan tugasnya sebagai guru yang ditetapkan dengan prinsip penghargaan atas dasar prestasi”.

Pemberian tunjangan profesi guru ini berkaitan dengan status kepegawaian guru yang bersangkutan seperti yang diatur dalam Peraturan Pemerintah No. 74 tahun 2008 tentang guru pasal 15, yang menyebutkan:

(1) Tunjangan profesi diberikan kepada Guru yang memenuhi persyaratan sebagai berikut:

(a) memiliki satu atau lebih Sertifikat Pendidik yang telah diberi satu nomor registrasi Guru oleh Departemen;

(b) memenuhi beban kerja sebagai Guru;

(c) mengajar sebagai Guru mata pelajaran dan/atauGuru kelas pada satuan pendidikan yang sesuai dengan peruntukan Sertifikat Pendidik yang dimilikinya;

(d) terdaftar pada Departemen sebagai Guru Tetap;

(e) berusia paling tinggi 60 (enam puluh) tahun; dan

(f) tidak terikat sebagai tenaga tetap pada instansi selain satuan pendidikan tempat bertugas.

(2) Seorang Guru hanya berhak mendapat satu tunjangan profesi terlepas dari banyaknya Sertifikat Pendidik yang dimilikinya dan banyaknya satuan pendidikan atau kelas yang memanfaatkan jasanya sebagai Guru.

Berdasarkan penjelasan diatas jelas terlihat bahwa guru yang berhak menerima tunjangan profesi dari pemerintah sebagai penghargaan atas profesi guru adalah para guru yang memiliki sertifikat pendidik. Sedangkan penghargaan Sebagaimana yang dikemukakan oleh Wibowo (2013:362) yang menyatakan pengertian penghargaan adalah:

"Atas pelaksanaan pekerjaan yang diberikan oleh manajer dan hasil yang diperoleh, pekerja mendapat upah atau gaji. Sementra itu, untuk meningkatkan kinerja, manajer menyediakan insentif bagi pekerja yang dapat prestasi kerja melebihi standar kinerja yang diharapkan.

Di luar upah, gaji, dan insentif seringkali pemimpin memberikan tambahan penerimaan yang lain sebagai upaya lebih menghargai kinerja pekerjanya. Dengan kata lain manajemen memberikan penghargaan atau reward".

Lebih lanjut Wibowo (2013:367) menjelaskan tipe penghargaan sebagai berikut:

"Tipologi penghargaan dapat dibedakan antara penghargaan ekstrinsik dan penghargaan intrinsik. Penghargaan ekstrinsik merupakan penghargaan finansial, materiil atau penghargaan sosial dari lingkungan. Sementara itu, penghargaan psikis merupakan penghargaan intrinsik karena bersifat Self-granted . seorang pekerja yang bekerja mencari penghargaan ekstrinsik, seperti uang atau pujian dikatakan termotivasi secara ekstrisnisk, sedangkan mereka yang memperoleh kesenangan dari tugas atau pengalaman merasa kompeten atau menentukan diri sendiri dikatakan termotivasi secata instrinsik. Arti pentingnya penghargaan ekstrinsik dan 
intrinsik semata-mata menyangkut masalah budaya dan selera pribadi”.

1) Penghargaan Ekstrinsik

Gibson, Ivancevich dan Donelly

dalam Wibowo (2013:367)

menyebutkan: penghargaaan ekstrinsik adalah penghargaan terhadap pekerjaan, seperti pembayaran, promosi, atau jaminan sosial. Sedangkan Kretiner dan Kinicki dalam Wibowo (et al) menyatakan sebagai penghargaan finansial, materiil atau sosial dari lingkungan. Dengan demikian dapat dikatakan bahwa penghargaan ekstrinsik merupakan penghargaan yang bersifat eksternal yang dibeikan terhadap kinerja yang telah diberikan oleh pekerja.

(a) Penghargaan Finansial

Upah dan gaji

Uang

merupakan penghargaan ekstrinsik utama, namun cara bekerjanya sering kurang dipahami. Keberhasilan memerlukan perhatian dan observasi secara hati-hati terhadap pekerja. Uang tidak akan menjadi motivator apabila pekerja tidak melihat hubungan antara kinerja dan peningkatan kompensasi.

Jaminan sosial

Fringe benefits atau jaminan sosial terutama finansial, tetapi beberapa diantaranya tidak seluruhnya finansial. Jaminan sosial finansial utama dalam banyak organisasi adalah program pensiun, asuransi kesehatan, dan liburan biasanya tidak tergantung pada kinerja.

Dalam banyak hal tergantung senioritas atau masa kerja.

(b) Penghargaan Interpersonal

Penghargaan interpersonal adalah penghargaan

ekstrinsik seperti menerima rekognisi atau pengakuan atau menjadi mampu berinteraksi sosial tentang pekerjaan. Manajer berperan dalam memberikan status pekerjaan sedangkan rekognisi merupakan pernyataan manajemen bahwa pekerjaan telah dilakukan dengan baik dan dapat

(c) Promosi

Manajer membuat keputusan penghargaan promosi sebagai usaha mencocokan orang tepat dengan pekerjaannya. Kriteria yang sering dipergunakan untuk mencapai keputusan promosi adalah kinerja dan senioritas. Kinerja, apabila dapat diukur secara akurat, sering memberi bobot penting dalam alokasi penghargaan promosi.

2) Penghargaan Intrinsik Gibson, Ivancevich dan Donelly dalam Wibowo (2013:369) menyatakan: Penghargaan intrinsik adalah merupakan bagian dari pekerjaan itu sendiri, seperti tanggung jawab, tantangan dan karakteristik umpan balik dari pekerjaan.

(a) Penyelesaian Pekerjaan

Kemampuan untuk memulai dan mengakhiri proyek atau pekerjaan mempunyai arti penting bagi individu. Orang 
menilai kinerja seseorang melalui kemampuan penyelesaian tugas. Pengaruh bahwa menyelesaikan tugas terdapat dalam dirinya merupakan self-reward.

Peluang yang memungkinkan orang dapat menyelesaikan tugas dengan baik atau pada waktunya dapat mempunyai pengaruh positif kuat. Terlebih lagi apabila keberhasilan pekerja tersebut mendapatkan penghargaan, akan menumbuhkan kepuasan kerja.

(b) Prestasi

Pencapaian prestasi adalah pencatatan sendiri penghargaan yang diperoleh dari mencapai tujuan menantang. Terdapat perbedaan individu dalam menentukan tujuan, ada yang mencari tujuan menantang, moderat atau rendah. Tujuan yang sulit dapat mengakibatkan tingkat kinerja individual tinggi daripada tujuan moderat. Oleh karena itu, disarankan untuk memberikan target pekerjaan cukup tinggi dan menantang, namun masih dapat dijangkau.

(c) Otonomi

Banyak orang yang menginginkan pekerjaan yang memberikan hak untuk membuat keputusan. Mereka ingin bekerja tanpa diawasi secara ketat. Perasaan otonomi dapat mengakibatkan kebebasan melakukan apa yang dipertimbangkan terbaik oleh pekerja. Dalam pekerjaan yang terstruktur sangat baik dan dikontrol manajemen, sulit menciptakan tugas yang mengarah pada perasaan otonomi. Pemberian otonomi secara luas merupakan bentuk pelibatan pekerja dalam pengambilan keputusan untuk meningkatkan tanggung jawabnya.

(d) Pengembangan Pribadi

Individu yang mengalami pertumbuhan dapat merasakan perkembangannya dan melihat bagaimana kapabilitasnya menjadi meluas. Dengan memperluas kapabilitas, pekerja dapat memaksimalkan atau memuaskan potensi keterampilan. Sebagian menjadi tidak puas jika tidak didorong mengembangkan keterampilannya. Program pengembangan sumber daya manusia melalui pendidikan dan pelatihan sangat berarti untuk mengembangkan kemampuan pekerja.

Dari paparan di atas sudah sangat jelas bahwasanya penghargaan merupakan salah satu faktor yang membangkitkan motivasi individu, penghargaan merupakan satu bentuk pengakuan atas apa yang dicapai oleh karyawan atau pekerja. Penghargaan diberikan secara situasional karena didasarkan atas pencapaian suatu prestasi pekerja. Keadaan ini sedikit berbeda dengan pemberian kompensasi, yang cenderung diberikan secara periodik atau reguler dalam bentuk gaji sesuai dengan tingkat atau golongan pekerja. Kompensiasi seperti yang dinyatakan oleh Cardoso dalam Danang Sunyoto (2013:153): 
"Kompensasi adalah segala sesuatu yang diterima oleh pekerja sebagai balas jasa atas kerja mereka. Masalah kompensasi berkaitan dengan konsisten internal dan konsisten eksternal. Konsisten internal berkaitan dengan konsep penggajian relatif dalam organisasi. Sedangkan konsisten eksternal berkaitan dengan tingkat struktur penggajian dalam organisasi dibandingkan dengan struktur penggajian yang berlaku di luar organisasi. Keseimbangan antara konsistensi internal dan konsistensi eksternal dianggap penting untuk diperhatikan guna menjadi perasaan puas dan para pekerja tetap termotivasi serta efektivitas bagi organisasi secara keseluruhan".

Pendapat S. Mangkuprawira dalam Danang Sunyoto (2013:154) tentang kompensasi adalah:

"Kompensasi merupakan sesuatu yang diterima karyawan sebagai penukar jasa mereka pada perusahaan. Dengan demikian kompensasi mengandung arti tidak sekedar hanya dalam bentuk finansial saja, seperti yang langsung berupa gaji, upah, komisi, dan bonus, serta tidak langsung berupa asuransi, bantuan sosial, uang cuti, uang pensiun, pendidikan dan sebagainya tetapi juga bukan bentuk finansial. Bentuk ini berupa pekerjaan dan lingkungan pekerjaan. Bentuk pekerjaan berupa tanggung jawab, perhatian, kesempatan dan penghargaan, sementara bentuk lingkungan pekerjaan berupa kondisi kerja, pembagian kerja, status dan kebijakan".

Berdasarkan pengertian yang dikemukakan para ahli di atas, dapat ditarik suatu kesimpulan bahwa
Kompensasi dan penghargaan merupakan bentuk pengakuan atas kontribusi karyawan kepada organisasi dan pencapaian atas prestasi kerja karyawan.

\section{METODOLOGI PENELITIAN Tempat Penelitian}

Tempat atau lokus penelitian adalah Sekolah Menengah Kejuruan (SMK) Negeri 57 Jakarta, yang berlokasi di Jalan Taman Margasatwa 38 B Jatipadang Pasar Minggu Jakarta.

\section{Metode Penelitian}

Penelitian ini menggunakan pendekatan kualitatif. Alasan utama menggunakan metode kualitatif adalah sesuai dengan tujuan penelitian, yaitu ; melakukan kajian terhadap keadaan saat ini yang terjadi di lokus penelitian, yang memperlihatkan gejala atau fenomena menuju ke arah munculnya suatu permasalahan. Akan tetapi permasalahan yang ada masih belum jelas, kompleks, dinamis, menyeluruh serta penuh makna. Permasalahan yang berhubungan dengan Pengelolaan Sumber Daya Manusia, sebagai faktor kunci dalam keberhasilan pelaksanaan proses belajar mengajar yang hasil akhirnya berkaitan dengan kualitas sumber daya manusia Indonesia. Informan terdiri dari para wakil kepala sekolah, dan guru. Pengumpulan data dilakukan dengan cara observasi, wawancara mendalam serta percakapan percakapan informal.

\section{HASIL PENELITIAN}

Deskripsi data hasil wawancara kepada para informan tentang mengemukakan pendapat atau ide- 
ide sebagai sarana memperbaiki komunikasi antara atasan dan bawahan menunjukkan data yang cukup baik. Manajemen SMK Negeri 57 Jakarta cukup terbuka dalam menerima masukan atau pendapat dari para guru dalam rangka perbaikan program yang ditetapkan oleh Manajemen SMK Negeri 57 Jakarta. Dengan sikap terbuka yang ditunjukkan oleh manajemen SMK Negeri 57 Jakarta dalam menampung aspirasi atau pendapat dari para guru, maka ada pemenuhan kebutuhan aktualisasi diri dapat terealisiasi. Sehinga kondisi ini dapat memotivasi para guru untuk bekerja sesuai dengan tugas pokok dan fungsinya.

Tindakan memotivasi lain yang dikemukakan oleh pra ahli adalah; berikan pengakuan. Seorang pemimpin cakap harus cepat memberikan pengakuan pada semua anggota tim atau organisasi, meski kontribusi pada keseluruhan tugas tidak langsung. Anda bekerja dengan prinsip "beri pujian bila layak dipuji”. Bila sebuah pekerjaan dihargai, akan selalu ada motivasi untuk melaksanakan pekerjaan itudan melaksanakannya dengan baik.

Hasil deskripsi data tentang pemberian penghargaan kepada para guru menunjukan jumlah yang sangat kecil. Kondisi demikian memberikan gambaran bahwa, manajemen SMK Negeri 57 Jakarta sangat kurang dalam hal memberikan penghargaan terhadap sesuatu yang dicapai oleh guru. Berdasarkan data yang tertera pada data display dapat diambil satu kesimpulan bahwa tindakan memotivasi yang bertujuan untuk membangun motivasi kerja guru belum sepenuhnya dilaksanakan oleh manajemen SMK Negeri 57 Jakarta.

\section{Analisis SWOT}

Analisis terakhir yang dilakukan dalam penelitian ini adalah analisis SWOT. Analisis SWOT yang dilakukan dalam penelitian ini terhadap strategi pengelolaan Suber daya manusia di lingkungan SMK Negeri 57 Jakarta. Dan motivasi kerja guru. Dalam analisis SWOT terhadap strategi pegelolaan Sumber Daya Manusia akan ditinjau dari dua faktor yaitu; faktor Internal dan eksternal. Berdasarkan identifikasi dan hasil wawancara dengan para informan penulis menjabarkan faktor-faktor internal dan eksternal sebagai berikut:

Faktor Internal (kekuatan) meliputi; Eksistensi SMK Negeri 57, Suber daya manusia, dukungan teknologi yang memadai, Lingkungan yang asri, Budaya Kerja yang baik. Dan faktor Internal yang menjadi kelemahan adalah; Sikap Inskonsistensi manajemen dalam menerapkan sistem, Sistemreward dan funsihment, tidak adanya program diklat untuk peningkatan konpetensi guru, tidak ada pemberian kompensasi selain yang diberikan oleh pemerintah, Gaya kepemimpinan yang tidak sesuai dengan keadaan saat ini. Sedangkan faktor eksternal sebagai peluang antara lain; jaminan/dukungan pemerintah pusat dan daerah, penyerapan lulusan oleh dunia Usaha/Industri, Program pendidikan yang direncanakan oleh pemerintah, Meningkatkan kesempatan bekerja dan berusaha bagi masyarakat, SMK juga berperan dalam mengurangi tingkat penganggur-an (jobless index) di Indonesia.

Faktor Eksternal yang menjadi ancaman sebagi berikut; Pesaing, 
SMK dan Pendidikan Tinggi Sejenis, Tamatan SLTP,

Sebagai intake Peserta didik SMK Pariwisata, Kurikulum yang berubah- ubah, Kondisi Sosio ekonomi masyrakat, Persaingan global terhadap keterampilan tenaga kerja yang setingkat dari luar negeri

\section{Kondisi SMK Negeri 57 Saat ini}

Tabel 4.25:

Matriks SWOT Strategi pengelolan SDM SMK Negeri 57 Jakarta

\begin{tabular}{|c|c|c|c|}
\hline \multicolumn{4}{|c|}{ ASPEK } \\
\hline \multicolumn{2}{|c|}{ Internal } & \multicolumn{2}{|c|}{ Eksternal } \\
\hline Kekuatan & Kelemahan & Peluang & Ancaman \\
\hline $\begin{array}{l}\text { Keberadaan } \\
\text { Negeri } 57 \text { Jakarta } \\
\text { diakui oleh peme- } \\
\text { rintah }\end{array}$ & $\begin{array}{lr}\text { Sikap } & \text { Inskonsis- } \\
\text { tensi } & \text { manajemen } \\
\text { dalam } & \text { menerapkan } \\
\text { sistem } & \end{array}$ & $\begin{array}{l}\text { Jaminan/Dukugan } \\
\text { dari Pemerintah pusat } \\
\text { dan Daerah tentang } \\
\text { kelang-sungan } \\
\text { Keberadaan SMK } \\
\text { Pariwisata }\end{array}$ & $\begin{array}{l}\text { Pesaing, SMK dan } \\
\text { Pendidikan Tinggi } \\
\text { Sejenis }\end{array}$ \\
\hline $\begin{array}{l}\text { Sumber } \\
\text { Manusia } \\
\text { besar dan } \\
\text { nuhi } \\
\text { nuhi kualifikasi } \\
\end{array}$ & $\begin{array}{l}\text { Rewards \& Funish- } \\
\text { ment yang tidak } \\
\text { jelas }\end{array}$ & $\begin{array}{l}\text { Penyerapan lulusan } \\
\text { untuk bekerja di } \\
\text { lingkup Regional } \\
\text { dan Internasional } \\
\end{array}$ & $\begin{array}{l}\text { Tamatan SLTP, } \\
\text { Sebagai intake } \\
\text { Peserta didik SMK } \\
\text { Pariwisata }\end{array}$ \\
\hline $\begin{array}{l}\text { Dukungan Tekno- } \\
\text { logi yang memadai }\end{array}$ & $\begin{array}{l}\text { Tidak adanya } \\
\text { program diklat } \\
\text { untuk peningkatan } \\
\text { kompetensi guru } \\
\text { yang terstruktur } \\
\text { dengan baik }\end{array}$ & $\begin{array}{l}\text { Peningkatan Program } \\
\text { jenjang pendidikan } \\
\text { yang direncanakan } \\
\text { oleh pemerintah }\end{array}$ & $\begin{array}{l}\text { Kurikulum yang } \\
\text { berubah-ubah }\end{array}$ \\
\hline $\begin{array}{l}\text { Lingkungan asri } \\
\text { dengan luas yang } \\
\text { sangat memadai }\end{array}$ & $\begin{array}{lr}\text { Tidak ada upaya } \\
\text { untuk memberikan } \\
\text { kompensasi terha- } \\
\text { dap guru selain apa } \\
\text { yang r sudah } \\
\text { diberikan } \\
\text { pemerintah }\end{array}$ & $\begin{array}{l}\text { Meningkatkan } \\
\text { kesempatan bekerja } \\
\text { dan berusaha bagi } \\
\text { masyarakat }\end{array}$ & $\begin{array}{l}\text { Kondisi Sosio } \\
\text { ekonomi masyrakat }\end{array}$ \\
\hline $\begin{array}{l}\text { Budaya Kerja yang } \\
\text { baik dan tumbuh } \\
\text { dalam diri masing- } \\
\text { masing individu }\end{array}$ & $\begin{array}{l}\text { Gaya kepemim- } \\
\text { pinan yang tidak } \\
\text { sesuai dengan } \\
\text { keadaan saat ini. }\end{array}$ & $\begin{array}{l}\text { SMK juga berperan } \\
\text { dalam mengurangi } \\
\text { tingkat penganggur- } \\
\text { an (jobless index) di } \\
\text { Indonesia. }\end{array}$ & $\begin{array}{l}\text { Persaingan global } \\
\text { terhadap } \\
\text { keterampilan tenaga } \\
\text { kerja yang setingkat } \\
\text { dari luar negeri }\end{array}$ \\
\hline
\end{tabular}

Tabel 4.26; Pembobotan Aspek-Aspek Internal Dan Eksternal untuk Strategi pengelolan SDM SMK Negeri 57 Jakarta

\begin{tabular}{|l|l|l|l|l|}
\hline \multicolumn{1}{|c|}{ Aspek Internal } & \multicolumn{1}{|c|}{ Nilai } & Skor & Bobot & $\begin{array}{c}\text { Skor } \\
\text { tertinggi }\end{array}$ \\
\hline Eksistensi SMK Pariwisata & Kuat & 3 & $10 \%$ & 0.3 \\
\hline Sumber daya Manusia & Kuat & 3 & $10 \%$ & 0.3 \\
\hline
\end{tabular}


JENIUS

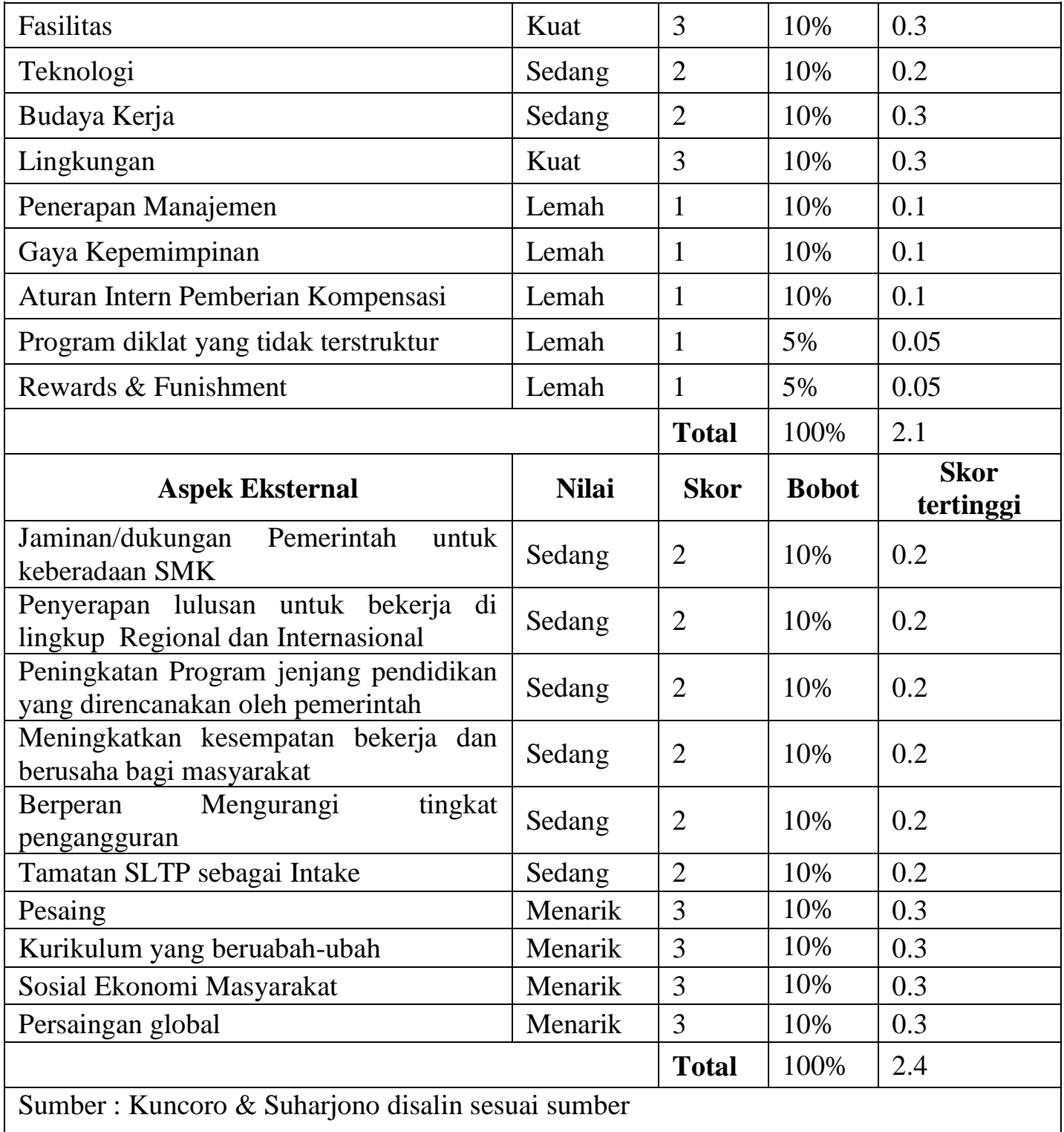

Berdasarkan matriks dan digambarkan sebagaimana tertera pembobotan Aspek-aspek Faktor pada halaman berikut

Internal dan Eskternal di atas, dapat 
Faktor Eksternal

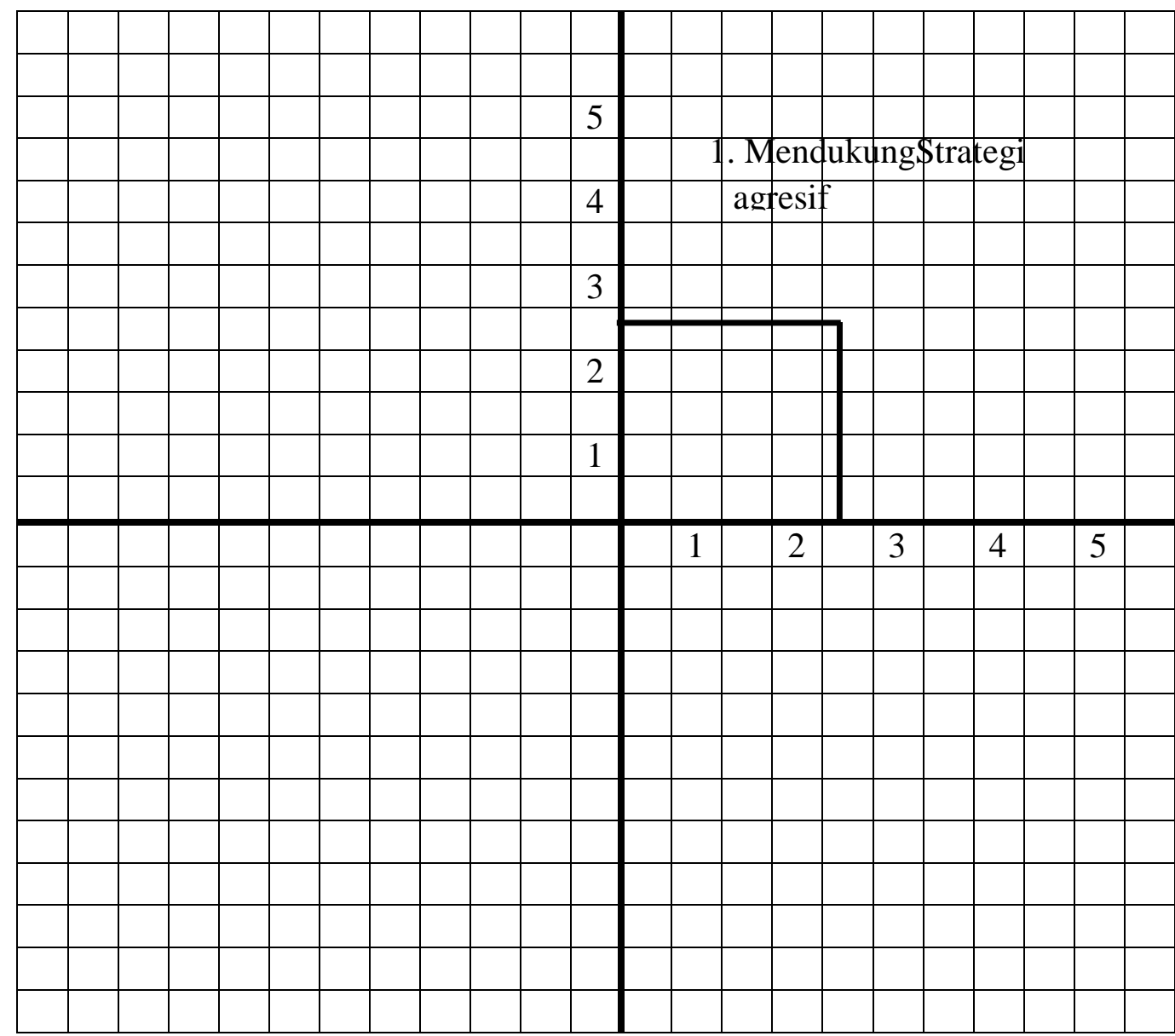

\section{Gambar 4.6: Koordinat Kuadran strategi SWOT}

Gambar 4.6 di atas merupakan koordinat kuadran analisis SWOT untuk Strategi pengelolan SDM SMK Negeri 57 Jakarta. Koordinat tersebut berada pada kuardan 1, yang menurut para ahli kuadran 1 menyebutkan; Ini merupakan situasi yang sangat menguntungkan. Perusahaan tersebut memiliki peluang dan kekuatan sehingga dapat memanfaatkan peluang yang ada. Strategi yang harus diterapkan dalam kondisi ini adalah mendukung kebijakan pertumbuhan yang agresif (Growth oriented strategy)

Mencermati hasil analisis SWOT yang berada pada kuadran 1, seyogyanya manajemen SMK Negeri 57 Jakarta berupaya untuk memperbaiki aspek-aspek yang memiliki nilai lemah, seperti; Penerapan Manajemen, Gaya Kepemimpinan, Aturan Intern Pemberian Kompensasi, Program diklat yang tidak terstruktur, Rewards \& Funishment.

Hasil identifikasi yang dilakukan oleh penulis untuk aspekaspek yang terdapat di dalam faktor Internal dan ekternal motivasi guru di SMK Negeri 57 Jakarta seperti terlihat pada tabel 45 di bawah ini; 
Tabel 4.27 ; Matriks Motivasi Kerja Guru

Analisis SWOT SMK Negeri 57 Jakarta

\begin{tabular}{|l|l|l|l|}
\hline \multicolumn{4}{|c|}{ ASPEK } \\
\hline Kekuatan & Kelemahan & Peluang & Ancaman \\
\hline Motif & $\begin{array}{l}\text { Mengugurkan } \\
\text { kewajiban }\end{array}$ & $\begin{array}{l}\text { Kenyamanan dalam } \\
\text { bekerja }\end{array}$ & Merasa tidak nyaman \\
\hline $\begin{array}{l}\text { Menyenangi } \\
\text { Pekerjaan }\end{array}$ & $\begin{array}{l}\text { Tanpa tujuan /Tidak } \\
\text { memiliki target }\end{array}$ & Eksistensi individu & Penolakan Lingkungan \\
\hline $\begin{array}{l}\text { Prestasi \& } \\
\text { Kepuasan Kerja }\end{array}$ & Cepat merasa puas & $\begin{array}{l}\text { Pengakuan/ } \\
\text { Penghargaan }\end{array}$ & $\begin{array}{l}\text { Minimnya } \\
\text { Kompensasi }\end{array}$ \\
\hline Komunikasi & Tidak dipercaya & $\begin{array}{l}\text { Aktualisasi diri/ } \\
\text { Jenjang karir } \\
\text { jabatan ada peningkatan }\end{array}$ \\
\hline
\end{tabular}

Tabel 4.28; Pembobotan Aspek-Aspek Faktor Internal Dan Eksternal Motivasi Kerja Guru SMK Negeri 57 Jakarta

\begin{tabular}{|c|c|c|c|c|}
\hline Aspek Internal & Nilai & Skor & Bobot & Skor tertinggi \\
\hline Motif & Kuat & 3 & $15 \%$ & 0.45 \\
\hline Menyenangi Pekerjaan & Kuat & 3 & $10 \%$ & 0.3 \\
\hline Prestasi \& Kepuasan Kerja & Kuat & 3 & $15 \%$ & 0.45 \\
\hline Eksistensi individu & Sedang & 2 & $15 \%$ & 0.3 \\
\hline Mengugurkan kewajiban & Sedang & 2 & $10 \%$ & 0.2 \\
\hline Tanpa tujuan /Tidak memiliki target & Lemah & 1 & $10 \%$ & 0.1 \\
\hline Cepat merasa puas & Lemah & 1 & $10 \%$ & 0.1 \\
\hline Tidak dipercaya & Lemah & 1 & $15 \%$ & 0.15 \\
\hline & & Total & $100 \%$ & 2.05 \\
\hline Aspek Eksternal & Nilai & Skor & Bobot & Skor tertinggi \\
\hline Kenyamanan dalam bekerja & Menarik & 3 & $15 \%$ & 0.45 \\
\hline Komunikasi & Lemah & 1 & $10 \%$ & 0.1 \\
\hline Pengakuan/ Penghargaan & Menarik & 3 & $15 \%$ & 0.45 \\
\hline Aktualisasi diri/ Jenjang karir & Sedang & 2 & $10 \%$ & 0.2 \\
\hline Merasa tidak nyaman & Sedang & 2 & $15 \%$ & 0,3 \\
\hline Salah faham & Menarik & 3 & $10 \%$ & 0,3 \\
\hline Minimnya Kompensasi & Menarik & 3 & $15 \%$ & 0,45 \\
\hline Tidak ada peningkatan jabatan & Sedang & 2 & $10 \%$ & 0,2 \\
\hline \multicolumn{2}{|c|}{ 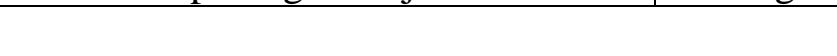 } & Total & $100 \%$ & 2,45 \\
\hline
\end{tabular}

Sumber : Kuncoro \& Suharjono disalin sesuai sumber

Kemudian dilanjutkan dengan membuat koordinat hasil pembobotan tersebut seperti yang terdapat pada gambar 17 pada bagian berikut. 


\section{Faktor Eksternal}

\begin{tabular}{|l|l|l|l|l|l|l|l|l|l|l|l|l|l|l|l|l|l|l|}
\hline & & & & & & & & & & & & & & & & & & \\
\hline
\end{tabular}

\section{Gambar 4.7: Koordinat Kuadran Motivasi Kerja Guru}

Koordinat kuadran Motivasi Kerja guru yang terdapat pada gambar 4.7 di atas menunjukan pada posisi kuadran 1, pendapat par ahli menyebutkan bahwa; kondidi ini merupakan situasi yang sangat menguntungkan. Perusahaan tersebut memiliki peluang dan kekuatan sehingga dapat memanfaatkan peluang yang ada. Strategi yang harus diterapkan dalam kondisi ini adalah mendukung kebijakan pertumbuhan yang agresif (Growth oriented strategy).

Kondisi demikian hendaknya dapat dimanfaatkan oleh manajemen SMK Negeri 57 Jakarta, dalam meningkatkan kualitas pendidikan pada jenjang SMK. Motivasi kerja guru yang sangat baik ini hendaknya dipertahankan oleh manajemen SMK Negeri 57 Jakarta. Aspek-aspek yang terdapat pada faktor eksternal memiliki skor pembobotan yang lebih besar jika dibandingkan dengan skor pembobotan aspek-aspek faktor internal, dapat menjadi ancaman bagi motivasi kerja guru. Jika kondisi ini terjadi terus-menerus atau tidak diperhatikan oleh manajemen tidak tertutp kemungkinan ada demotivasi bagi para guru, jika aspek-aspek faktor internal semakin tertekan oleh aspek-aspek faktor eksternal.

Kebijakan pertumbuhan yang agresif (Growth oriented strategy) 
dapat ditempuh dengan menerapkan fungsi-fungsi manajemen dengan sesungguhnya dalam setiap pelaksanaan kebijakan yang ditetapkan. Melaksanakan pengelolaan SDM dengan sebenarbenarnya yang meliputi seluruh aspek-aspek yang terdapat pada faktor Internal dan eksternal dalam Motivasi kerja guru.

Sebagai bagian akhir dalam analisis ini, penulis mengambil kesimpulan bahwa manajemen SMK Negeri 57 Jakarta belum secara konsisten menerapkan semua fungsi manajemen dalam pelaksanaan kebijakan atau program. Manajemen SMK Negeri 57 Jakarta kurang memperhatikan aspek-aspek pengakuan dan penghargaan kepada setiap individu, serta kurang memperhatikan aspek komunikasi dalam setiap pelaksanaan kebijakan dalam operasional manajemen.

\section{G. Analisis BCG Consulting Group)}

Untuk lebih lengkap dalam melakukan analisis di dalam penulisan penelitian ini, penulis menambah satu analisis yaitu analissi BCG. Metode analisis Boston Consulting Group (BCG) merupakan metode yang digunakan dalam menyusun suatu perencanaan unit bisnis strategic dengan melakukan pengklasifikasian terhadap potensi keuntungan perusahaan (http://info.okeygan.com/2012/07/co ntoh-pengerjaan-bcg-matriks.html, Kotler, 2002).

Data tentang penelusuran tamatan tersebut seperti yang tertera pada tabel 4.29 di bawah ini.

Tabel 4.29: Keterserapan Tamatan Siswa SMK Pariwisata Program Studi Usaha Perjalanan Wisata (UPW)

\begin{tabular}{|c|c|c|c|c|c|c|c|}
\hline \multirow[b]{2}{*}{ No } & \multirow[b]{2}{*}{ SMK } & \multirow[b]{2}{*}{ Tahun } & \multicolumn{3}{|c|}{ Jumlah } & \multirow[b]{2}{*}{$\begin{array}{l}\text { Jumlah } \\
\text { Tamatan }\end{array}$} & \multirow{2}{*}{$\begin{array}{c}\text { Keter- } \\
\text { serapan } \\
\%\end{array}$} \\
\hline & & & $\begin{array}{l}\text { Melan- } \\
\text { jutkan }\end{array}$ & Bekerja & $\begin{array}{l}\text { Lain- } \\
\text { Lain }\end{array}$ & & \\
\hline \multirow[t]{3}{*}{1} & SMK N 57 & $2012 / 2013$ & 23 & 26 & 0 & 49 & 100 \\
\hline & & $2013 / 2014$ & 27 & 27 & 2 & 56 & 96,43 \\
\hline & & $2014 / 2015$ & 36 & 16 & 2 & 54 & 96,43 \\
\hline \multirow[t]{3}{*}{2} & SMK N 33 & $2012 / 2013$ & 3 & 5 & 23 & 31 & 26 \\
\hline & & $2013 / 2014$ & 6 & 15 & 8 & 29 & 72 \\
\hline & & $2014 / 2015$ & 12 & 6 & 14 & 32 & 56,25 \\
\hline \multirow[t]{3}{*}{3} & SMK N 60 & $2012 / 2013$ & 7 & 21 & 3 & 31 & 90,32 \\
\hline & & $2013 / 2014$ & 11 & 15 & 3 & 29 & 89,65 \\
\hline & & $2014 / 2015$ & 3 & 19 & 6 & 28 & 78,57 \\
\hline
\end{tabular}

Sumber: Diolah Berdasarkan Sumber

Berdasarkan data yang tertera pada tabel 4.29 di atas, dapat terbaca bahwa tingkat kestabilan dari keterserapan tamatan dimiliki oleh SMK Negeri 57 Jakarta. Dimana tingkat keterserapan mencapai $100 \%$ pada periode 2012/2013, 96,43\% pada periode 2013/2014 dan tetap pada angka 96, $43 \%$ pada periode 2014/2015. Sedangkan tingkat pertumbuhan yang dimiliki oleh SMK Negeri 33 Jakarta untuk 
keterserapan tamatan menunjukan fluktuasi yang cukup signifikan. SMK Negeri 33 memiliki prosentase sebesar $26 \%$ pada periode tahun 2012/2013, $72 \%$ pada periode 2013/2014, dan $56,25 \%$ pada periode 2014/2015. Selanjutnya data keterserapan tamatan SMK Negeri

Untuk memperjelas tentang posisi dari masing-masing SMK Di atas, berikut disajikan matriks BCG berdasarkan data yang tertera pada tabel 4.29 di atas.

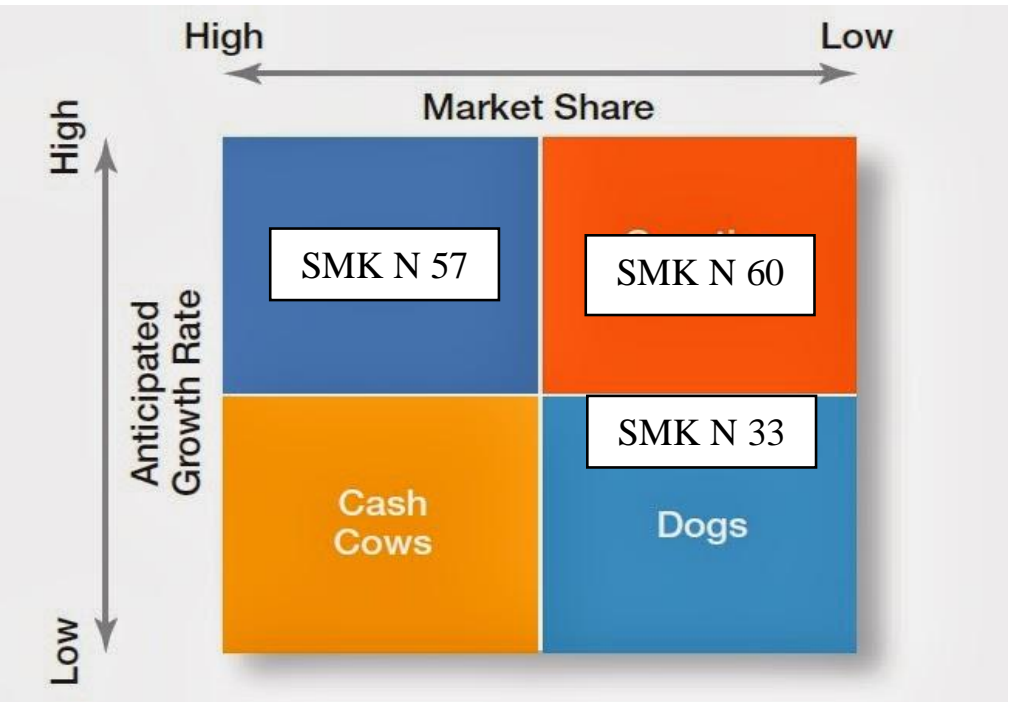

Gambar 4.8: Matrik BCG Keterserapan Tamatan SMK Pariwisata Program Studi UPW

$\begin{array}{cc}\text { Penjelasan dari matriks } & \text { BCG } \\ \text { diatas, sebagai berikut; } & \text { perlu }\end{array}$ diketahui mengapa data yang disajikan untuk keterserapan tamatan di pusatkan pada program studi Usaha Perjalanan Wisata (UPW), kondisi disebabkan karena tidak diperoleh data dari dua SMK yang menjadi sumber data khususnya SMK Negeri 60 untuk program Studi Perhotelan dan Jasa Boga. Alasan lain adalah program studi Jasa Boga dan Perhotelan relatif lebih banyak lapangan pekerjaannya jika dibandingkan dengan program studi Usaha Perjalanan Wisata. Kondisi nyata di dunia industri jumlah Hotel dan Restoran lebih banyak
60 Jakarta, menunjukkan penurunan dalam 3 tahun terakhir. Pada peiode 2012/2013 prosentase keterserapan tamatan mencapai $90,32 \%$, pada periode 2013/2014 terjadi penurunan menjadi 89,65 \%, dan kembali mengalami penuruan pada periode 2014/2015 menjadi 78,57\%. 


\section{PENUTUP}

Sebagai bagian akhir dalam penulisan penelitian ini, akan dikemukakan kesimpulan yang dibuat berdasarkan analisis data

\section{Kesimpulan}

Setelah melakukan analisis data dan preposisi yang dikemukakan pada Bab 4, maka kesimpulan yang dikemukakan sebagai berikut:

1. Manajemen SMK Negeri 57 Jakarta, tidak memiliki konsistensi dalam menerapkan kebijakan manajemen secara umum, pengelolaan program kegiatan, pendelegasian tugas dan wewenang sehubungan dengan pelaksanaan tugas dan tanggung jawab sebagai guru.

2. SMK Negeri 57 Jakarta belum memiliki ketetapan untuk pemberian reward dan funishment, pemberian penghargaan dan sangsi hanya berdasarkan ketetapan dari Pemerintah provinsi dan pemerintah pusathal ini berkaitan dengan Pengelolaan Sumber daya manusia, pemerataan keikutsertaan dalam kegiatan, penghargaan atas pencapaian prestasi yang dicapai oleh para guru.

3. Manajmemen SMK Negeri 57 Jakarta tidak pernah merencanakan suatu program yang ditujuka untuk Pemberian motivasi dalam bentuk tindakan memotivasi sehingga guru mau mengerahkan segenap kemampuan yang dimilikinya dalam melaksanakan tugas dan menghasilkan tamatan yang sesuai dengan tujuan pendidikan nasional.
4. Manajemen SMK Negeri 57 Jakarta belum memberikan rasa nyaman dan aman kepada setiap guru karena manajemen SMK Negeri 57 Jakarta tidak mengasuransikan guru dan karyawan sebagai bentuk perlindungan untuk memberikan rasa aman dan nyaman dalam bekerja.

\section{Saran-saran}

1. Manajemen SMK Negeri 57 Jakarta, hedaknya tetap konsisten dalam menerapkan kebijakan membangun motivasi kerja guru, dan menyusun suatu perencanaan tentang pelatihan untuk membangun motivasi kerja guru yang tertuang di dalam program kerja kepala sekolah dan wakil kepala sekolah.

2. Manajemen SMK Negeri 57 Jakarta harus merancang atau membuat suatu ketetapan untuk pemberian reward dan funishment, sehinggapemberian penghargaan (reward) dan sangsi (funishment) tidak hanya berdasarkan ketetapan dari Pemerintah provinsi dan pemerintah pusat.

3. Manajemen SMK Negeri 57 Jakarta hendaknya berusaha untuk meningkatkan penghasilan guruguru di SMK Negeri 57 Jakarta yang sudah bisa memenuhi kebutuhan dasar. Dengan melibatkan semua guru dalam kegiatan unit produksi yang ada di lingkungan SMK Negeri 57 Jakarta.

4. Manajemen SMK Negeri 57 Jakarta henaknya memberikan rasa nyaman dan aman kepada setiap guru dengan mengasuransikan guru dan 
karyawan sebagai bentuk perlindungan untuk memberikan rasa aman dan nyaman dalam bekerja.

\section{Rekomendasi}

Sebagai masukan kepada pihak manajemen SMK Negeri 57 Jakarta, penulis memberikan alternatif pemecahan masalah yang terjadi di lingkungan SMK Negeri 57 Jakarta dengan rekomendasi yang diusulkan pada penelitian ini. Rekomendasi yang diajukan ada dua jenis rekomenasi, yaitu; rekomendasi operasional dan rekomendasi konseptual.

\section{Rekomendasi Operasional}

Rekomendasi operasional yang diajukan sebagai berikut:

a. Berdasarkan analisis data hasil wawancara tentang strategi program yang direncanakan oleh manajemen SMK Negeri 57 Jakarta tentang pelatihan yang bertujuan membangung motivasi kerja guru, tidak direncanakan dalam program kerja baik program kerja kepala sekolah, program kerja wakil kepala sekolah. Maka menurut pendapat penulis manajemen SMK Negeri 57 Jakarta segera menyusun perencanaan program pelatihan yang bertujuan membangun motivasi kerja guru di SMK Negeri 57 Jakarta.

b. Sehubungan dengan pengakuan keberadaan individu dan kelompok di lingkungn SMK Negerii 57 Jakarta, maka manajemen SMK Negeri 57 Jakarta melakukan identifikasi keberdaan kelompok baik secara formal maupun informal. Sehingga keberadaan kelompok-kelompok di lingkungan SMK Negeri 57 Jakarta dapat dijadikan wadah untuk menjalin komunikasi yang baik antara manajemen SMK Negeri 57 Jakarta dengan para guru.

\section{Rekomendasi Konseptual.}

Rekomendasi ini berdasarkan pendapat dari Malayu S.P. Hasibuan. Adapun konsep yang dikemukakan oleh Malayu S.P. Hasibuan sebagaimana yang terlihat pada gambar di bawah ini:

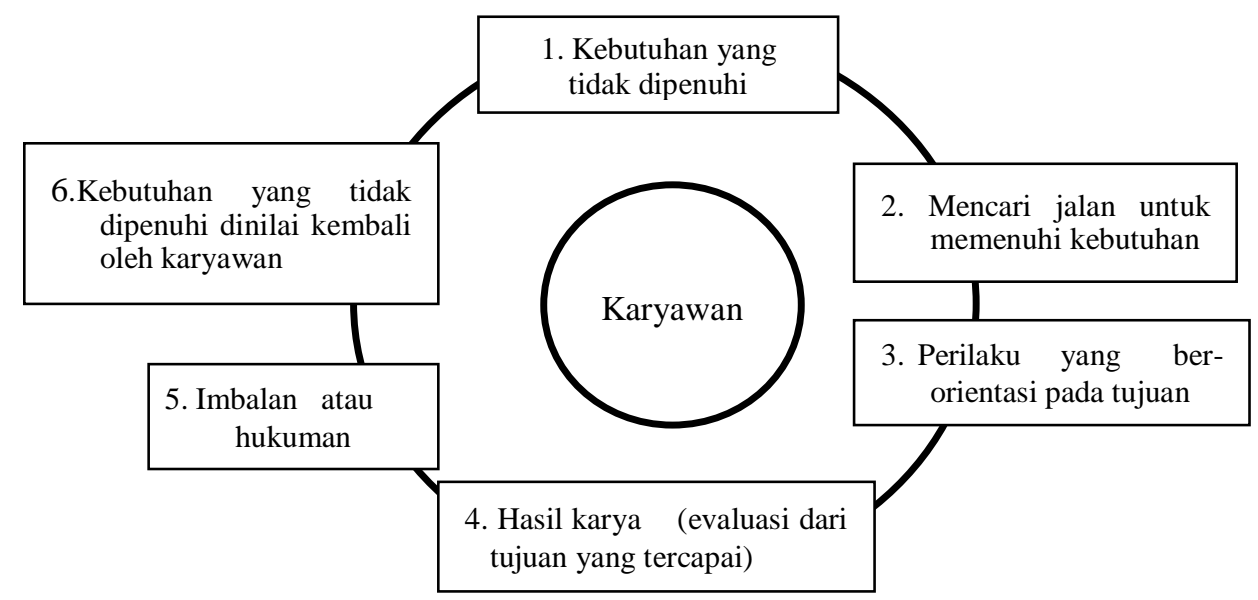

Sumber : Malayu S.P. Hasibuan disalin berdasarkan sumber. 


\section{a. Langkah Pertama}

Berdasarkan alur pemikiran yang disampaikan pada gambar di atas, manajemen SMK Negeri 57 Jakarta harus mengidentifikasi kebutuhan-kebutuhan yang tidak terpenuhi di kalangan para guru. Berdasarkan hasil analisis data dan wawancara seperti yang telah dipaparkan pada Bab 4, diperoleh data bahwa kebutuhan-kebutuhan yang tidak terpenuhi di kalangan para guru adalah: keamanan \& kenyamanan, Prestasi kerja, yang termasuk kedalam faktor internal, sedangkan Komunikasi, Kelompok, dan Imbalan yang termasuk ke dalam faktor eksternal.

\section{b. Langkah Kedua}

Setelah teridentifikasi semua kebutuhan guru yang tidak terpenuhi, maka manajemen SMK Negeri 57 dapat mencari jalan atau menentukan langkah-langkah pemecahan untuk memecahkan permasalahpermasalahan tersebut. Seperti;

1) Keamanan dan Kenyamanan Untuk memberikan rasa aman dan nyaman dalam melaksanakan tugas sehari-hari di SMK Negeri 57 Jakarta, para guru bisa saja diikut sertakan dalam program asuransi yang mencakup semua resiko yang dihadapai oleh para guru dalam melaksanakan tugas baik sejak berangkat dari rumah, di sekolah dan kembali lagi ke rumah. Dengan pendanaan yang di ambil dari hasil/pendapatan unit produksi yang ada di SMK Negeri 57 Jakarta.

2) Penghargaan atas Prestasi kerja Sistem pemberian penghargaan dan sangsi yang belum jelas, di lingkungan SMK Negeri 57 Jakarta. Cenderung menimbulkan sikap demotivasi di kalangan para guru, untuk itu perlu segera dirumuskan sistem pemberian penghargaan atas setiap prestasi kerja yang dicapai oleh para guru. selain itu juga perlu ditegakan disiplin kerja atau penegakan peraturan tentang pemberian sangsi kepada para guru yang melakukan tindakan indisipliner atau pelanggaran tata tertib aatau peraturan disiplin kerja guru. pemberian penghargaan ini mencakup pemberian kompensasi yang dapat merangsang motivasi kerja guru dalam melaksanakan tugas seharihari.

3). Komunikasi

Masalah komunikasi yang terjadi selama ini adalah komunikasi satu arah dan tidak menjangkau seluruh guru, dimana kebijakan yang disampaikan kepada para guru hanya diterima oleh orangorang tertentu sehingga ada orang guru yang tidak menerima informasi yang disampaikan oleh pihak manajemen. Untuk mengatasi masalah ini, manajemen SMK Negerui 57 Jakarta bisa memanfaatkan keberadaan kelompok-kelompok yang ada di SMK Negeri 57 Jakarta sebagai perantara untuk menyampaikan informasi kepada para guru. bisa juga dengan dilakukan secara elektronik dengan sosial media yang terdapat pada jalur 
internet, masalahnya tidak semua guru tergabang dalam komunitas sosial media tersebut. Sarana lain bisa juga disampaikan secara tertulis dan disampaikan langsung kepada guru-guru yang bersangkutan.

\section{4). Kelompok}

Keberadaan kelompokkelompok di SMK Negeri 57 Jakarta tidak dapat dihindari oleh manajemen SMK Negeri 57 Jakarta. Kelompok ini terbentuk baik karena ikatan mata pelajaran sejenis atau program studi maupun ikatan jenis kelamin serta merasa senasib karena kurang diperhatikan oleh manajemen. Kelompok-kelompok yang terbentuk berdasarkan program studi memang mendapat pengakuan secara resmi oleh manajemen SMK Negeri 57 Jakarta, terbukti dengan adanya ketua program studi. Sedangkan keberadaan kelompok-kelompok yang terbentuk atas dasar ikatan jenis kelamin dan ikatan perasaan senasib karena diabaikan oleh manajemen, perlu mendapat perhatian oleh manajemen SMK Negeri 57 Jakarta.

Kelompok-kelompok kecil ini bisa menjadi suatu kekuatan jika bisa dimanfaarkan oleh manajemen dalam rangka mencapai tujuan organisasi. Untuk itu perlu diberikan suatu pengakuan walaupun tidak secara formal agar perasaan diabaikan oleh manajemen bisa diminimalisir. Pengakuan ini dapat berbentuk pemberian kepercayaan dalam pelaksanaan suatu kegiatan, sehingga merekan merasa eksistensinya diakui oleh manajemen SMK Negeri 57 Jakarta.

5) Imbalan

Untuk masalah pemberian imbalan kepada guru kiranya manajemen SMK Negeri 57 Jakarta tidak hanya terpaku kepada apa yang sudah diberikan oleh pemerintah, baik pemerintah pusat maupun propinsi. Selama ini manajemen SMK Negeri 57 Jakarta selalu berdalih sudah menjadi TUPOKSI (tugas pokok dan fungsi), jika tidak ingin memberikan imbalan atas setiap kegiatan atau tugas yang dibebankan kepada guru.

Sebagai aparatur sipil negara, guru yang sebagai Pegawai Negeri Sipil berkewajiban menjalankan tuga yang sudah menjadi TUPOKSI-nya. Tetapi jika tugas yang dibebankan diluar jam kerja dan hari kerja kiranya sudah sepantasnya jika guru mendapatkan apreasi dari lembaga atau SMK Negeri 57 Jakarta dalam pelaksanaan atugas tersebut. Manajemen SMK Ngeri 57 Jakarta hendaknya bisa memilah-milah tugas yang pokok dan tugas tambahan yang dilaksanakan diluar tuga pokoknya.

\section{c. Langkah Ke tiga.}

Langkah ke tiga dalam gambar ini adalah perilaku yang berorientasi kepada tujuan. Pemberian pemahaman tentang tujuan organisasi yang telah ditetapkan oleh 
manajemen SMK Negeri 57 Jakarta, kepada para guru dapat dilakukan pada saat kegiatan rapat kerja sekolah. Selama ini manajemen SMK Negeri 57 Jakarta kurang memperhatikan tentang pemahaman tujuan organisasi ini. Penyampaian informai tentang kebijakan manajemen berhenti pada lingkup wakil kepala sekolah dan tidak sampai kepada para guru. sehingga diperlukan suatu wadah untuk memberikan pemahaman tentang kebijakan manajemen khususnya tentang tujuan organisasi.

Pemberian pemahaman tujuan organisasi akan sangat berguna bagi para guru dan memberi arah dalam penyusunan rencana kerja yang akan dilaksanakan pada tahun ajaran baru. Untuk mengarahkan perilaku yang berorientasi kepada tujuan organisai, maka diperlukan suatu pelatihan untuk membangun motivasi bagi para guru. Pada saat pelaksanaan pelatihan ini manajemen dapat melakukan pemahaman tentang tujuan organisasi yang akan dicapai pada periode yang akan datang. Dengan disampaikannya tujuan organisasi pada saat pelatihan tersebut, maka lalam kelamaan akan tertanam di dalam pikiran para guru. Sehingga kondisi ini akan mampu menumbuhkan perilaku guru dalam melaksanakan tugasnya yang berorientasi kepada tujuan organisasi.

\section{d. Langkah ke empat}

Langkah ke empat dalam konsep proses motivasi adalah Hasil karya (evaluasi dari tujuan yang tercapai). Dalam setiap pelaksanaan suatu kegiatan atau program, ada satu tahap yang haru dilakukan untuk mengetahui ketercapaian program tersebut. Tahap yang dimaksud adalah evaluasi program, dalam pelakasanaan evaluasi program biasanya dilakukan perbandingan antara rencana kerja yang dirumuskan dan ketercapaian dari rencana kerja tersebut.

Dalam proses motivasi ini dihubungan dengan kebutuhan yang tidak tercapai, maka perlu ditinjau ulang penyebab dari tidak tercapainya kebutuhan tersebut. Banyak faktor yang menyebabkan tidak tercapainya kebutuhan tersebut, faktor tersebut bisa dari lingkup eksternal seperti organisasi maupun internal individu. Jika penyebab tidak tercapainya kebutuhan tersebut berasal ari faktor eksternal, maka perlu dilakukan perbaikan terhadap perencanaan dan pelakasanaan program di lembaga yang dalam hal ini SMK Negerii 57 Jakarta. Jika penyebabnya dari faktor internal atau individu, maka perlu ditelaah kembali kondisi individu yang bersangkutan dan diupayakan suatu tindakan untuk memperbaiki kondisi indvidu yang berangkutan. Misalnya diberikan suatu bentuk kegiatan yang bisa membangkitkan kembali kondisi fisik atau psikis individu.

\section{e. Langkah ke lima}

Langkah ke lima adalah memberikan Imbalan atau hukuman atas pretasi dan pelanggaran disiplin bagi para guru. Pemberian imbalan atau hukuman hendaknya dirumuskan dan disesuaikan dengan kondisi lembaga. Seperti yang udah dikemukakan pada bagian sebelumnya, bahwa SMK Negeri 57 Jakarta belum memiliki rumusan yang sesuai dengan kondisi guru untuk pemberian imbalan dan hukuman. 
Dalam suatu lembaga atau organisasi pemberian imbalan atau hukuman atas pencapaian suatu prestasi kerja dan pelanggaran disiplin merupakan suatu kewajaran. Sangat tidak mungkin orang melakukan pelanggaran tanpa diberikan sangsi atu hukuman, dan tidak wajar juga jika ada seseorang yang memiliki prestasi kerja yang baik tidak diberikan suatu penghargaan. Pemberian hukuman ditujukan untuk memberikan efek jera agar tidak melakukan pelanggaran lagi dan memperbaiki kinerjanya dimasa yang akan datang. Sebaliknya memberikan penghargaan atas suatu prestasi kerja dapat menjadi pendorong kepada individu yang dalam hal ini adalah para guru untuk lebih giat lagi dalam mengerahkan segenap kemampuan yang dimillikinya dlam melaksanakann tugas. Sehingga mencapai hasil yang terbaik.

\section{f. Langkah ke enam}

Langkah terakhir dalam proses motivasi adalah melakukan penilaian kembali atas kebutuhan yang tidak dipenuhi oleh karyawan. Langkah ini merupakan tindakan yang dilakukan oleh individu atau guru untuk mengevaluasi diri mereka sendiri. Dengan kata lain langkah ini merupakan otokritik bagi para guru di lingkungan SMK Negeri 57 Jakarta. Dengan melakukan penilaian kembali atas kebutuhan yang tidak terpenuhi, diharapkan para guru menyadari apa yang menjadi kekurangan dalam dirinya. Jika kelemahan diri sudah ditemukan, akan menyadarkan guru atau individu yang bersangkutan tentang penyebab tidak terpenuhinya kebutuhan tersebut. Hasil akhir yang diharapkan dari penilaian kembali atas kebutuhan yang tidak terpenuhi adalah para guru tidak hanya menuntut kepada manajemen SMK Negeri 57 Jakarta untuk memenuhi kebutuhan para guru. Akan tetapi guru yang bersangkutan berusaha secara mandiri untuk memenuhi kebutuhannya, dalam setiap pelaksanaan tugas sesuai dengan profesinya.

\section{DAFTAR PUSTAKA}

Adair John, 2008, "Kepemimpinan Yang Memotivasi", Aturan "Lima Puluh Lima Puluh" dan Delapan Prinsip Utama Untuk Memotivasi, PT. Gramedia Pustaka Utama, Jakarta.

Ahmad

Saebani,2013,"Manajeme

n Penelitian", Pengantar : Prof. Dr. Tajul Arifin, MA. Pustaka Setia, Bandung

Alwi Syafaruddin, 2001, "Manajemen Sumberdaya Manusia, Strategi Keunggulan Kompetitif", edisi pertama, BPFE, Yogyakarta.

Bungin Burhan, 2015, "Analisis Data Penelititan Kualitatif", Pemahaman Filosofis dan Metodologis ke Arah Pengasaan Model Aplikasi. PT. RajaGrafindo Persada, Jakarta. 


\section{JENIUS}

Handoko T. Hani, 2009, "Manajemen" edisi 2, BPFE, Yogyakarta. 2010 "Manajemen Personalia \& Manajemen Sumberdaya Manusia" edisi 2, BPFE, Yogyakarta.

Hasibuan Malayu S.P, 2011, "Manajemen, Dasar, Pengertian, dan Masalah" Edisi Revisi, PT. Bumi Aksara, Jakarta

"Manajemen Sumber Daya Manusia", Edisi Revisi, PT. Bumi Aksara, Jakarta

Martalena Saur, 2013, "Pengaruh Kepemimpinran Kepala Sekolah Dan Motivasi Berprestasi Terhadap Kepuasan Kerja Guru Sekolah Menengah Kejuruan Kelompok Pariwisata Di Wilayah Jakarta Selatan", Penelitian, UHAMKA, Jakarta

Mondy R. Wayne, 2008, "Manajemen Sumber Daya Manusia", Jilid 1 Edisi 10, Erlangga, Jakarta

Nawawi Hadari, 2008, "Manajemen Sumber Daya Manusia" Untuk Bisnis Yang Kompetetitif, Gajah Mada University Press, Yogyakarta.
Nurfuadi, 2012, "Profesionalisme Guru", Editor: Suwito.Ns. STAIN Pres, Purwokerto.

P. Robbins Stephen \& Mary Coutler, 2010,"Manajemen" edisi ke sepuluh, Erlangga Jakarta.

Prabu Mangkunegara, A.A. Anwar, 2013, "Manajemen Sumber Daya Manusia Perusahaan", Rosda Karya, Bandung

Riduwan, 2013,"Metode dan teknik Menyusun Penelitian" Pengantar Buchari Alma, Alfabeta, Bandung

Rusilowati Umi,2013,"Manajemen Pengetahuan Berbasis Teknologi Informasi dalam Konteks Pembelajaran Organisasi", Asmoro Mediatama, Tangerang Selatan

Sedarmayanti, 2009, "Sumber Daya Manusia dan Produktivitas Kerja", CV. Mandar Maju, Jakarta Sumber Daya Manusia, Reformasi Birokrasi dan Manajemen Pegawai Negeri Sipil " Reflika ADITAMA, Bandung.

Siagian, P.Sondang, 2012,'Teori Motivasi dan Aplikasinya"

Supriyatna Deden, Andi Sylvana, 2011, 
Penerbit Universitas

Terbuka, Jakarta.

Sri Subandini Yuliani, 2011,

"Analisis Pengaruh

Motivasi Kerja Dan

Keterampilan

Kepemimpinan Terhadap

Kecepatan Pelayanan

Perawat Di Rawat Inap

Rumah Sakit Pondok

Indah", Penelitian,

Universitas Pamulang

Tangerang

Sugiyono,2007,"Metode Peneltian

Pendidikan", (Pendekatan kuantitatif Kualitatif dan R\&D), Alfabeta, Bandung

2014,"Memahami
Penelitian Kualitatif"
Alfabeta, Bandung

Sunyoto

Danang,

2013,

"Manajemen Sumber Daya Manusia" CAPS (Centre for Academic Publishing Service), Jakarta.

Tisnawati Sule Ernie, 2012, "Pengantar Manajemen" Kencana Prenada Media Grup, Jakarta

Undang-Undang Republik Indonesia Nomor 20 Tahun 2003 Tentang Sistem Pendidikan Nasional

Yamin Martinis, 2012, "Desain Baru Pembelajaran Konstruktivistik", Referensi, Jakarta
Yuniarsih, Tjutju, 2011, "Manajemen Sumber Daya Manusia” Teori, Aplikasi dan Isu Penelitian, Alfabeta Bandung.

Wibowo, 2013,"Manajemen Kinerja", Edisi Ke tiga, Rajawali Pers, Jakarta

Williams Kate, 2006, "Introducing Management", Third Edtion, Butterworth Heinemann, Burlington, USA.

\section{Jurnal}

Anonim,"Makna Profesionalisme Guru", http://guru dan profesionalisme.

blogspot.com/2010/05/ma knaprofesionalismeguru.html, diakses tanggal 27 Maret 2014)

\section{Anonim, "Menkeu: Kualitas SDM Indonesia Masih Rendah" \\ http://berita.plasa.msn.com /bisnis/beritasatu/menkeu- kualitas-sdm-indonesia- masih-rendah-1 Diakses tanggal 11 maret 2014}

Henry, "Definisi Motivasi Kerja" (http://teorionline.wordpre ss.com/ 2010/ 01/25/definisi-motivasikerja/ diakses tanggal 28 Maret 2014)

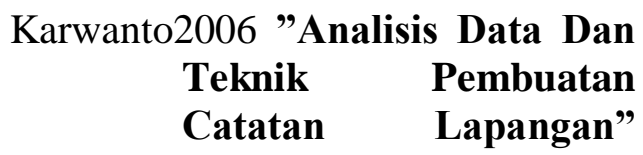


(Dilengkapi dengan

Contoh-contoh)

https://www.academia.edu /5356965/ANALISIS_DA

TA_DAN_TEKNIK_PEM BUATAN_CATATAN_L APANGAN_Dilengkapi_d engan_Contoh-

contoh_Oleh_Karwanto/ diakses tanggal 8 Oktober 2015

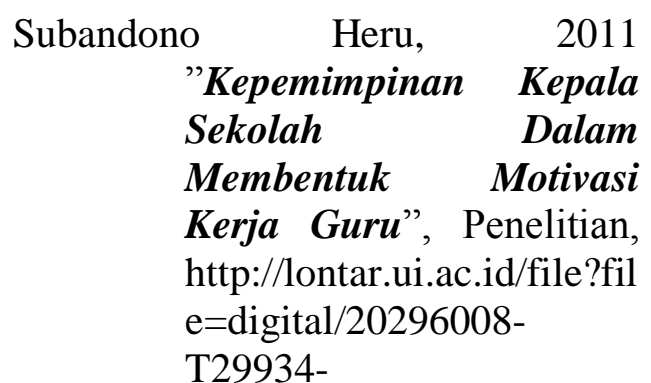

Heru\%20Subandono.pdf.

Dikases tanggal 18 Maret 2014

UNDP, 2013, "Summary Human Development Report 2013"

(http://hdr.undp.org/sites/d efault/files/hdr2013_en_su mmary.pdf Diakses tanggal 14 Maret 2014

Wasito Tririno

Raharjo http://www.lontar.ui.ac.id/ file?file $=$ digital $/ 131608$ $\mathrm{T}+27554-$

Strategi+meningkatkanTinjauan+literatur.pdf diakses tanggal 5 